\title{
Sistem Pendukung Keputusan Kelayakan Pemberian Pinjaman dengan Metode Analytical Hierarchy Process (AHP) dan Simple Additive Weighting (SAW)
}

\author{
Kecitaan Harefa \\ Teknik Informatika, Universitas Pamulang, Jl. Raya Puspitek No.46, Buaran, Serpong, Tangerang \\ Selatan, Banten, Indonesia, 15310 \\ e-mail: kecitaan21@gmail.com
}

Submitted Date: December 09 ${ }^{\text {th }}, 2019$

Revised Date: May $13^{\text {th }}, 2020$
Reviewed Date: December $11^{\text {th }}, 2019$

Accepted Date: June $30^{\text {th }}, 2020$

\begin{abstract}
Cipta Harapan Jaya Cooperative Savings and Loans is a financial institution that provides loan funds to the community, namely micro, small and medium entrepreneurs. Lending is done with a system and procedure that is easy, fast and safe. But many customers do not fulfill their obligations or are not fluent in paying installments, thereby causing bad credit and reducing cooperative income. The cause of customers who are not fluent in paying installments cannot be detected with the current selection system for prospective customers. This research proposes the use of a decision support system with the Analytical Hierarchy Process (AHP) method used to determine the criteria weights and the Simple Additive Weighting ( $S A W)$ method to find the best alternative. Both of these methods can facilitate the cooperative in making decisions about prospective customers who apply for loans more effectively and efficiently. The criteria used are collateral, capital, condition, capacity, and character. Based on the results of the calculation and implementation of the proposed method obtained an accuracy of 90.67\%. This means that this accuracy is close to good value and can be used as a guideline for determining potential customers who are eligible for loans.
\end{abstract}

Keywords: AHP; SAW; Savings and Loans; Credit

Abstrak

Koperasi Simpan Pinjam Cipta Harapan Jaya merupakan sebuah lembaga keuangan yang menyediakan dana pinjaman kepada masyarakat, yaitu para pengusaha mikro, kecil dan menengah (UMKM). Pemberian pinjaman dilakukana dengan sistem dan prosedur yang mudah, cepat dan aman. Tetapi nasabahnya banyak yang tidak memenuhi kewajibannya atau tidak lancar dalam membayar angsuran, sehingga menyebabkan kredit macet dan mengurangi pendapatan koperasi. Penyebab nasabah tidak lancar dalam membayar angsuran belum dapat dideteksi dengan sistem seleksi penerimaan calon nasabah saat ini. Pada penelitian ini diusulkan penggunaan sistem pendukung keputusan dengan metode Analytical Hierarchy Process (AHP) yang digunakan untuk menentukan bobot kriteria dan metode Simple Additive Weighting (SAW) untuk mencari alternatif terbaik. Kedua metode ini dapat memudahkan pihak koperasi dalam mengambil keputusan terhadap calon nasabah yang mengajukan pinjaman dengan lebih efektif dan efisien. Kriteria yang digunakan adalah collateral, capital, condition, capacity, dan character. Berdasarkan hasil penghitungan dan implementasi metode yang diusulkan didapat akurasi 90,67\%. Artinya akurasi ini mendekati nilai baik dan dapat dijadikan salah satu pedoman untuk menentukan calon nasabah yang layak mendapatkan pinjaman.

Kata Kunci: AHP; SAW; Simpan Pinjam; Kredit

\section{Pendahuluan}

Koperasi adalah badan usaha yang beranggotakan orang seorang atau badan hukum 
dengan melandaskan kegiatannya berdasarkan atas asas kekeluargaan (Dedeh \& Nana, 2017). Sistem ekonomi yang cocok bagi masyarakat Indonesia adalah sistem ekonomi tertutup yang bersifat kekeluargaan atau ekonomi rumah tangga, yaitu dari anggota, oleh anggota dan untuk anggota. Diharapkan kepada setiap anggota yang telah mendapatkan pinjaman untuk mengembalikan angsuran tepat waktu demi mempertahankan keberlangsungan hidup koperasi. Koperasi didirikan bertujuan untuk meningkatkan kesejahteraan para anggotanya. Untuk itu, menjadi anggota sebuah koperasi dapat memberikan banyak keuntungan. Salah satunya untuk menambah penghasilan (Suryani, Ustriyana \& Wulandira, 2016).

Angsuran tidak lancar disebabkan oleh kurangnya pengawasan dari koperasi untuk menangih kredit yang diberikan kepada nasabah. Selain itu, juga disebabkan oleh ketidakmampuan nasabah membayar kredit kepada koperasi (Suarjaya, 2015). Keberlangsungan hidup koperasi bukan karena besarnya pinjaman yang diberikan tetapi kemampuan nasabah dalam membayar kredit kepada pihak koperasi sesuai dengan waktu yang telah ditentukan.

Koperasi Simpan Pinjam Cipta Harapan Jaya memberikan dana pinjaman kepada masyarakat, yaitu para pengusaha mikro, kecil dan menengah (UMKM) dengan sistem dan prosedur yang mudah, cepat dan aman, sehingga banyak peminat dari calon nasabah yang menginginkan pinjaman tersebut. Masalah yang dihadapi saat ini oleh Koperasi Simpan Pinjam Cipta Harapan Jaya adalah banyak nasabahnya yang tidak lancar dalam membayar angsuran, sehingga menyebabkan kredit macet dan mengurangi pendapatan koperasi. Saat ini, Koperasi Simpan Pinjam Cipta Harapan Jaya mengambil keputusan untuk calon nasabah yang berhak mendapat pinjaman hanya berdasarkan jaminannya tanpa harus mempertimbangkan kriteria-kriteria penting lainnya seperti collateral, capital, condition, capacity, dan character yang juga menjadi faktor penting dalam pemberian kredit atau pinjaman.

Pemberian pinjaman terhadap nasabah, pihak koperasi tentu menghadapi risiko atau masalah, salah satunya adalah kredit macet. Kredit macet disebabkan karena nasabah mengalami kesulitan pelunasan akibat adanya faktor-faktor tertentu (Nursyahriana, Michael \& Irsan, 2017). Penyebab terjadinya angsuran tidak lancar berasal dari internal koperasi, nasabah, dan eksternal atau alam. Faktor dari internal koperasi, yaitu kelemahan dalam menganalisa kredit, kurangnya pengawasan, dan kelemahan sumber daya manusia. Faktor dari nasabah, yaitu kelemahan karakter nasabah, nasabah mengalami musibah (Armana, Trisna \& Erni, 2015). Karena Koperasi Simpan Pinjam Cipta Harapan Jaya menerapkan prosedur yang mudah dalam menyetujui pegajuan pinjaman, maka banyak calon nasabah yang ingin mencoba-coba mengajukan pinjaman.

Penyebab nasabah tidak melunasi kewajibannya kepada pihak koperasi belum dapat dideteksi dengan sistem seleksi penerimaan calon nasabah saat ini. Padahal mendeteksi nasabah yang berisiko tidak membayar kredit pada tahap permohonan kredit sangat penting (Chosyali \& Sartono, 2019), karena dapat digunakan untuk mencegah timbulnya kredit bermasalah yang menyebabkan kerugian pihak pemberi pinjaman (Sabri, 2016). Kredit macet tidak hanya di Koperasi Simpan Pinjam Cipta Harapan Jaya, tetapi juga terjadi pada semua pihak pemberi kredit baik perbankan maupun dengan modal sendiri (Faiza, Diana \& Cholid, 2018).

Analytical Hierarchy Process (AHP) merupakan metode pengambilan keputusan dengan melibatkan sejumlah kriteria dan alternatif. Metode Simple Additive Weighting (SAW) adalah metode yang digunakan untuk mencari alternatif terbaik dari sejumlah alternatif (Kitnas \& Feddy, 2015). Kedua metode ini digunakan untuk menentukan calon nasabah yang berhak menerima pinjaman berdasarkan data-data ketika mengajukan pinjaman.

Koperasi perlu menganalisa pinjaman yang akan diberikan kepada calon nasabah apakah dapat dikembalikan sesuai dengan waktu yang telah ditentukan atau tidak. Hal ini dilakukan supaya tidak terjadi kredit macet (Suci \& Nurhayati, 2018).

Metode Sistem Pendukung Keputusan (SPK) yang dapat digunakan untuk mencari alternatif terbaik, yaitu Simple Additive Weighting (SAW), Weighted Product (WP), Technique for Order Preference by Similarity to Ideal Solution (TOPSIS), Profile Matching, Analytic Hierarchy Process (AHP) (Ernawati, Nur \& Elvi, 2017).

Maka pada penelitian ini akan diterapkan metode AHP dan SAW. Diharapkan kedua metode ini dapat membantu koperasi Simpan Pinjam Cipta Harapan Jaya untuk menentukan kelayakan nasabah menerima kredit.

\section{Penelitian Terkait}


Dalam melakukan penelitian penerapan metode AHP dan SAW untuk menentukan kelayakan pemberian pinjaman perlu dilakukan review terhadap penelitian terkait. Review yang dilakukan bertujuan untuk mengetahui kendala yang ada dan hasil yang telah dicapai oleh peneliti lain. Dengan melakukan review, maka dapat memperoleh alternatif metode-metode yang dapat digunakan untuk menyelesaikan masalah.

Penelitian yang dilakukan oleh Siti, Nurul dan Suprapto (Siti, Nurul \& Suprapto, 2018) dinyatakan bahwa dalam hal menentukan pemberian kredit, untuk mencegah adanya masalah dan resiko kredit maka sistem pendukung keputusan sangat diperlukan. Penelitian ini menggunakan metode AHP-SAW. Metode ini dipilih karena mampu menangani permasalahan yang memiliki banyak kriteria untuk memperoleh alternatif yang diharapkan. AHP menghasilkan bobot dari setiap kriteria. Bobot ini digunakan dalam penghitungan SAW. Hasil penelitian menunjukkan bahwa metode AHP-SAW memiliki akurasi sebesar $89 \%$. Artinya metode ini dapat digunakan.

Penelitian yang dilakukan oleh Bayu dan Anwar (Bayu \& Anwar, 2018) dinyatakan bahwa dalam penentuan kelayakan nasabah penerima kredit, kriteria-kriteria yang harus diperhatikan antara lain jaminan, jumlah pinjaman, penghasilan dan jangka waktu pinjaman. Pada penelitian ini metode yang digunakan adalah metode AHP yang dapat mempermudah dalam pengambilan keputusan. Hasil dari penelitian yang telah dilakukan menunjukkan bahwa metode AHP dapat membantu koperasi dalam pengambilan keputusan untuk pemberian kredit kepada calon nasabah.

Penelitian yang dilakukan oleh Ari Wibowo dan Keanu (Ari Wibowo \& Keanu, 2017) dinyatakan bahwa pemberian kredit harus memperhatikan kriteria-kriteria nasabah yang benar-benar layak mendapatkan kredit dari pihak pemberi kredit. Oleh karena itu, semua calon nasabah yang mengajukan kredit belum tentu bisa mendapatkannya. Hal ini diperlukan suatu sistem pendukung keputusan yang digunakan menentukan apakah calon nasabah layak menerima kredit atau tidak, dengan sistem ini maka lebih mudah untuk memperhitungkan kriteria-kriteria nasabah yang berhak mendapatkan kredit. Selain itu, supaya sistem pengambilan keputusan terhadap calon nasabah lebih terintegrasi dan memiliki data yang valid. Penghitungan SPK didasarkan data nasabah yang sudah tersedia. Kriteria-kriteria yang diperhatikan adalah pengasilan, jumlah tanggungan, pinjaman lain, kemampuan pembayaran dan jaminan. Penelitian ini menggunakan metode Simple Additive Weighting dengan mencari penjumlahan terbobot dari kriteria setiap alternatif yang ada. Metode Simple Additive Weighting dapat membandingkan semua alternatif. Hasil penelitian menunjukkan bahwa metode SAW berhasil menghitung data nasabah sehingga dengan mudah dilakukan pengambilan keputusan.

Penelitian yang dilakukan oleh Anita dan Purnomo (Anita \& Purnomo, 2019) dinyatakan bahwa kesalahan serta penyimpangan data sering terjadi dalam pemberian kredit, untuk mencegah hal tersebut perlu adanya sistem pengambilan keputusan. Untuk mendapatkan keputusan yang maksimal maka digunakan metode Simple Additive Weighting (SAW) dengan kriteria penilaian yaitu gaji, pendapatan lain, pinjaman lain, dan jaminan. Hasil penelitian menunjukkan bahwa berdasarkan data yang diuji memiliki akurasi sebesar $90 \%$.

\section{Metodologi}

Metode yang digunakan pada penelitian ini adalah metode Analytical Hierarchy Process (AHP) dan Simple Additive Weighting (SAW). Kriteria yang digunakan dalam pengambilan keputusan ini yaitu collateral, capital, condition, capacity, dan character. AHP digunakan untuk mencari nilai bobot pada setiap kriteria dan SAW digunakan untuk mencari alternatif terbaik. Kedua metode ini dapat membantu Koperasi Simpan Pinjam Cipta Harapan Jaya untuk menentukan calon nasabah yang layak menerima pinjaman. Langkah-langkah yang dilakukan dalam penentuan calon nasabah yang layak memperoleh pinjaman pada Koperasi Simpan Pinjam Cipta Harapan adalah menggunakan metode AHPSAW.

Pembobotan Menggunakan metode Analytical Hierarchy Process (AHP)

1. Menentukan prioritas kriteria

Data matriks perbandingan kriteria adalah data yang didapatkan langsung dari objek penelitian melalui hasil pengamatan lapangan dan wawancara dengan pimpinan Koperasi Simpan Pinjam Cipta Harapan Jaya. Spesifikasi dataset matriks perbandingan kriteria yang telah dikumpulkan ditunjukkan pada Tabel 1 .

Tabel 1. Matriks Perbandingan Berpasangan

\begin{tabular}{|l|l|l|l|l|l|}
\hline K & C1 & C2 & C3 & C4 & C5 \\
\hline
\end{tabular}




\begin{tabular}{|c|c|c|c|c|c|}
\hline $\mathrm{C} 1$ & 1 & 2 & 3 & 3 & 5 \\
\hline $\mathrm{C} 2$ & 0.5 & 1 & 2 & 3 & 3 \\
\hline $\mathrm{C} 3$ & 0.33 & 0.5 & 1 & 2 & 3 \\
\hline $\mathrm{C} 4$ & 0.33 & 0.33 & 0.5 & 1 & 2 \\
\hline C5 & 0.2 & 0.33 & 0.33 & 0.5 & 1 \\
\hline Jml & $\mathbf{2 . 3 6}$ & $\mathbf{4 . 1 6}$ & $\mathbf{6 . 8 3}$ & $\mathbf{9 . 5}$ & $\mathbf{1 4}$ \\
\hline
\end{tabular}

Keterangan:

$$
\begin{aligned}
& \mathrm{K}=\text { Kriteria } \\
& \mathrm{Jml}=\text { Jumlah } \\
& \text { Prio = Prioritas } \\
& \mathrm{C} 1=\text { Collateral } \\
& \mathrm{C} 2=\text { Capital } \\
& \mathrm{C} 3=\text { Condition } \\
& \mathrm{C} 4=\text { Capacity } \\
& \mathrm{C} 5=\text { Character } \\
& \text { Ket = Keterangan } \\
& \mathrm{A}=\text { Alternatif } \\
& \mathrm{L}=\text { Lancar } \\
& \mathrm{TL}=\text { Tidak Lancar }
\end{aligned}
$$

\begin{tabular}{|l|l|l|l|l|l|l|l|} 
C4 & 0.14 & 0.08 & 0.07 & 0.11 & 0.14 & $\mathbf{0 . 5 4}$ & $\mathbf{0 . 1 1}$ \\
\hline C5 & 0.08 & 0.08 & 0.05 & 0.05 & 0.07 & $\mathbf{0 . 3 4}$ & $\mathbf{0 . 0 7}$ \\
\hline
\end{tabular}

Angka 0.42 pada kolom collateral baris collateral didapat dari pembagian angka pada kolom collateral baris collateral dengan jumlahnya yang terdapat pada Tabel 1. Angkaangka yang ada pada kolom dan baris kriteria didapat dengan cara yang sama. Angka yang ada pada kolom jumlah didapat dengan menjumlahkan angka-angka kriteria yang ada pada baris tersebut, seperti jumlah pada baris collateral merupakan hasil penjumlahan dari $0.42+0.48+0.44+0.32+0.36=2.02$. Sedangkan angka-angka yang ada pada kolom prioritas didapatkan dengan membagi angka pada kolom jumlah dengan jumlah elemen, dimana jumlah elemen yang digunakan lima buah. Angka pada kolom prioritas baris collateral didapat dari $2.02 / 5=0.40$.

3. Matriks penjumlahan setiap baris

Tabel 3. Matriks Penjumlahan Setiap Baris menunjukkan bahwa perbandingan antara kriteria yang sama memiliki nilai 1 , seperti terlihat pada kolom collateral dengan baris collateral memiliki nilai 1 begitu juga antara kolom capital dengan baris capital, kolom condition dengan baris condition, kolom capacity dengan baris capacity, kolom character dengan baris character. Angka 2 pada kolom capital dan baris collateral menunjukkan bahwa antara collateral dan capital merupakan dua nilai pertimbangan yang berdekatan. Angka 3 pada kolom condition dan baris collateral menunjukkan bahwa elemen collateral sedikit lebih penting daripada elemen condition. Angka 5 pada kolom character dan baris collateral menunjukkan bahwa elemen collateral lebih penting dibanding character. Begitu juga dengan perbandingan kriteria lainnya. Sedangkan angka 0.5 pada kolom collateral dan baris capital didapat dari 1/nilai pada kolom capital baris collateral yaitu 2, sehingga didapatkan nilai 0.5. Angka-angka yang lain diperoleh dengan cara yang sama. Nilai-nilai dari setiap kolom kriteria dijumlahkan diletakan pada baris jumlah.

2. Membuat matriks nilai kriteria

Tabel 2. Matriks Nilai Kriteria

\begin{tabular}{|c|c|c|c|c|c|c|c|}
\hline K & C1 & C2 & C3 & C4 & C5 & Jml & Prior \\
\hline C1 & 0.42 & 0.48 & 0.44 & 0.32 & 0.36 & $\mathbf{2 . 0 2}$ & $\mathbf{0 . 4 0}$ \\
\hline C2 & 0.21 & 0.24 & 0.29 & 0.32 & 0.21 & $\mathbf{1 . 2 8}$ & $\mathbf{0 . 2 6}$ \\
\hline C3 & 0.14 & 0.12 & 0.15 & 0.21 & 0.21 & $\mathbf{0 . 8 3}$ & $\mathbf{0 . 1 7}$ \\
\hline
\end{tabular}

\begin{tabular}{|c|c|c|c|c|c|c|}
\hline K & $\mathbf{C 1}$ & $\mathbf{C 2}$ & $\mathbf{C 3}$ & $\mathbf{C 4}$ & $\mathbf{C 5}$ & Jml \\
\hline C1 & 0.40 & 0.51 & 0.50 & 0.32 & 0.34 & $\mathbf{2 . 0 7}$ \\
\hline C2 & 0.20 & 0.26 & 0.33 & 0.32 & 0.20 & $\mathbf{1 . 3 2}$ \\
\hline C3 & 0.13 & 0.13 & 0.17 & 0.22 & 0.20 & $\mathbf{0 . 8 4}$ \\
\hline C4 & 0.13 & 0.08 & 0.08 & 0.11 & 0.13 & $\mathbf{0 . 5 4}$ \\
\hline C5 & 0.08 & 0.08 & 0.05 & 0.05 & 0.07 & $\mathbf{0 . 3 4}$ \\
\hline
\end{tabular}

Nilai yang terdapat di kolom collateral baris collateral (0.40) didapat dari hasil kali nilai prioritas pada Tabel $2(0.40)$ dengan nilai yang ada pada kolom collateral pada Tabel 1 (1). Nilai pada kolom capital baris collateral (0.51) didapat dari hasil kali nilai prioritas Tabel 2 (0.26) dengan nilai pada kolom capital dan baris collateral Tabel 1 (2). Begitu juga cara untuk mendapatkan nilai yang ada disetiap baris dan kolom kriteria. Sedangkan nilai yang ada di kolom jumlah merupakan hasil penjumlahan baris kriteria, misalnya pada baris collateral (2.07) hasil dari $0.40+0.51+0.50+$ $0.32+0.34$.

4. Penghitungan Rasio Konsistensi

Tabel 4. Penghitungan Rasio Konsistensi

\begin{tabular}{|c|c|}
\hline $\mathbf{K}$ & $\operatorname{Lamda}(\boldsymbol{\lambda})$ \\
\hline $\mathrm{C} 1$ & 5.14 \\
\hline $\mathrm{C} 2$ & 5.16 \\
\hline $\mathrm{C} 3$ & 5.08 \\
\hline
\end{tabular}




\begin{tabular}{|c|c|}
$\mathrm{C} 4$ & 5.02 \\
\hline $\mathrm{C} 5$ & 5.07 \\
\hline Total & $\mathbf{2 5 . 4 7}$ \\
\hline $\boldsymbol{\lambda}_{\text {maks }}$ & $\mathbf{5 . 0 9}$ \\
\hline
\end{tabular}

Nilai yang terdapat pada baris collateral didapat dari hasil pembagian nilai jumlah baris collateral pada Tabel 3 (2.07) dengan nilai prioritas collateral pada Tabel 2 (0.40). begitu juga cara untuk mendapatkan nilai yang ada disetiap baris pada kolom Lamda $(\lambda)$. Misalnya pada baris collateral (5.14) hasil dari 2.07/0.40.

Untuk mencari nilai Consistency Index (CI) dan nilai Consistency Ratio (CR) dengan rumus sebagai berikut:

$$
\begin{gathered}
C I=\frac{\lambda \text { maks }-n}{n-1} \\
C I=\frac{5.09-5}{5-1} \\
C I=\frac{0.09}{4} \\
C I=0.02 \\
C R=\frac{C I}{R I} \\
C R=\frac{0.02}{1.12} \\
C R=\mathbf{0 . 0 2}(\text { ACCEPTABLE })
\end{gathered}
$$

Nilai Consistency Ratio (CR) yang diperoleh menunjukkan $\leq 0.1$ maka penghitungan bobot tersebut sudah bisa digunakan. Selanjutnya bobot tersebut digunakan untuk penghitungan SAW.

\section{Pemeringkatan menggunakan metode Simple Additive Weighting (SAW)}

1. Nilai Setiap Nasabah

Data dikumpulkan dari berkas-berkas nasabah yang telah mendapatkan pinjaman yang diperoleh dari bagian administrasi Koperasi Simpan Pinjam Cipta Harapan Jaya. Data yang digunakan adalah data pemberian kredit 1 tahun terakhir sebanyak 75 nasabah. Spesifikasi dataset nilai setiap nasabah yang telah dikumpulkan ditunjukkan pada Tabel 5.

Tabel 5. Nilai Setiap Nasabah

\begin{tabular}{|c|c|c|c|c|c|}
\hline \multirow{2}{*}{ A } & \multicolumn{5}{|c|}{ Kriteria } \\
\cline { 2 - 6 } & C1 & C2 & C3 & C4 & C5 \\
\hline A1 & 70 & 30 & 60 & 40 & 100 \\
\hline
\end{tabular}

\begin{tabular}{|c|c|c|c|c|c|}
\hline A2 & 40 & 30 & 60 & 70 & 80 \\
\hline A3 & 80 & 60 & 40 & 30 & 60 \\
\hline A4 & 60 & 50 & 70 & 60 & 70 \\
\hline A5 & 40 & 60 & 50 & 70 & 90 \\
\hline A6 & 50 & 80 & 70 & 70 & 60 \\
\hline A7 & 70 & 70 & 60 & 80 & 90 \\
\hline A8 & 80 & 70 & 70 & 60 & 100 \\
\hline A9 & 80 & 60 & 70 & 50 & 60 \\
\hline A10 & 50 & 70 & 50 & 80 & 90 \\
\hline A11 & 60 & 70 & 70 & 60 & 80 \\
\hline A12 & 70 & 60 & 80 & 70 & 70 \\
\hline A13 & 70 & 60 & 70 & 60 & 70 \\
\hline A14 & 80 & 70 & 70 & 50 & 60 \\
\hline A15 & 70 & 80 & 60 & 70 & 90 \\
\hline A16 & 90 & 70 & 60 & 70 & 80 \\
\hline A17 & 70 & 60 & 80 & 80 & 70 \\
\hline A18 & 80 & 90 & 70 & 70 & 80 \\
\hline A19 & 80 & 60 & 70 & 60 & 70 \\
\hline A20 & 90 & 90 & 70 & 50 & 70 \\
\hline A21 & 70 & 80 & 70 & 70 & 100 \\
\hline A22 & 70 & 80 & 70 & 60 & 70 \\
\hline A23 & 80 & 70 & 80 & 60 & 80 \\
\hline A24 & 70 & 70 & 60 & 80 & 90 \\
\hline A25 & 80 & 90 & 80 & 70 & 100 \\
\hline A26 & 70 & 80 & 60 & 70 & 70 \\
\hline A27 & 80 & 90 & 70 & 90 & 70 \\
\hline A28 & 90 & 70 & 70 & 80 & 60 \\
\hline A29 & 80 & 60 & 70 & 60 & 100 \\
\hline A30 & 70 & 60 & 70 & 80 & 90 \\
\hline A31 & 70 & 70 & 80 & 60 & 70 \\
\hline A32 & 90 & 70 & 70 & 80 & 60 \\
\hline A33 & 70 & 60 & 80 & 90 & 90 \\
\hline A34 & 80 & 80 & 90 & 60 & 70 \\
\hline A35 & 80 & 90 & 70 & 70 & 90 \\
\hline A36 & 60 & 70 & 70 & 80 & 80 \\
\hline A37 & 90 & 70 & 70 & 70 & 80 \\
\hline A38 & 80 & 70 & 80 & 60 & 70 \\
\hline A39 & 80 & 80 & 70 & 80 & 60 \\
\hline A40 & 70 & 70 & 60 & 70 & 70 \\
\hline A41 & 80 & 70 & 70 & 60 & 80 \\
\hline A42 & 90 & 70 & 80 & 60 & 100 \\
\hline A43 & 80 & 90 & 70 & 90 & 70 \\
\hline
\end{tabular}




\begin{tabular}{|c|c|c|c|c|c|} 
A44 & 90 & 70 & 70 & 80 & 70 \\
\hline A45 & 80 & 70 & 80 & 70 & 70 \\
\hline A46 & 70 & 60 & 70 & 80 & 70 \\
\hline A47 & 90 & 80 & 70 & 70 & 80 \\
\hline A48 & 70 & 80 & 70 & 80 & 60 \\
\hline A49 & 90 & 80 & 70 & 80 & 90 \\
\hline A50 & 80 & 70 & 80 & 70 & 70 \\
\hline A51 & 80 & 80 & 70 & 80 & 90 \\
\hline A52 & 90 & 80 & 90 & 70 & 70 \\
\hline A53 & 70 & 60 & 60 & 70 & 80 \\
\hline A54 & 60 & 70 & 70 & 80 & 70 \\
\hline A55 & 70 & 70 & 80 & 70 & 80 \\
\hline A56 & 80 & 60 & 60 & 70 & 80 \\
\hline A57 & 70 & 70 & 80 & 70 & 80 \\
\hline A58 & 80 & 70 & 70 & 80 & 80 \\
\hline A59 & 80 & 70 & 90 & 80 & 70 \\
\hline A60 & 60 & 70 & 60 & 80 & 70 \\
\hline A61 & 80 & 70 & 80 & 70 & 90 \\
\hline A62 & 70 & 60 & 80 & 70 & 80 \\
\hline A63 & 90 & 80 & 70 & 80 & 70 \\
\hline A64 & 90 & 70 & 70 & 80 & 60 \\
\hline A65 & 70 & 80 & 70 & 80 & 90 \\
\hline A66 & 90 & 80 & 70 & 70 & 80 \\
\hline A67 & 70 & 70 & 80 & 60 & 80 \\
\hline A68 & 80 & 70 & 70 & 80 & 60 \\
\hline A69 & 90 & 70 & 70 & 80 & 70 \\
\hline A70 & 70 & 70 & 80 & 80 & 70 \\
\hline A71 & 80 & 70 & 80 & 90 & 70 \\
\hline A72 & 70 & 80 & 90 & 70 & 100 \\
\hline A73 & 90 & 60 & 70 & 70 & 80 \\
\hline A74 & 60 & 80 & 80 & 70 & 100 \\
\hline A75 & 90 & 70 & 70 & 80 & 80 \\
\hline & & & & \\
\hline
\end{tabular}

2. Membuat normalisasi Tabel 6.

Data hasil normalisasi ditunjukkan pada

Tabel 6. Hasil Normalisasi

\begin{tabular}{|c|c|c|c|c|c|}
\hline \multirow{2}{*}{ A } & \multicolumn{5}{|c|}{ Kriteria } \\
\cline { 2 - 6 } & C1 & C2 & C3 & C4 & C5 \\
\hline A1 & 0.78 & 0.33 & 0.67 & 0.44 & 1.00 \\
\hline A2 & 0.44 & 0.33 & 0.67 & 0.78 & 0.80 \\
\hline
\end{tabular}

\begin{tabular}{|c|l|l|l|l|l|}
\hline A3 & 0.89 & 0.67 & 0.44 & 0.33 & 0.60 \\
\hline A4 & 0.67 & 0.56 & 0.78 & 0.67 & 0.70 \\
\hline A5 & 0.44 & 0.67 & 0.56 & 0.78 & 0.90 \\
\hline A6 & 0.56 & 0.89 & 0.78 & 0.78 & 0.60 \\
\hline A7 & 0.78 & 0.78 & 0.67 & 0.89 & 0.90 \\
\hline A8 & 0.89 & 0.78 & 0.78 & 0.67 & 1.00 \\
\hline A9 & 0.89 & 0.67 & 0.78 & 0.56 & 0.60 \\
\hline A10 & 0.56 & 0.78 & 0.56 & 0.89 & 0.90 \\
\hline A11 & 0.67 & 0.78 & 0.78 & 0.67 & 0.80 \\
\hline A12 & 0.78 & 0.67 & 0.89 & 0.78 & 0.70 \\
\hline A13 & 0.78 & 0.67 & 0.78 & 0.67 & 0.70 \\
\hline A14 & 0.89 & 0.78 & 0.78 & 0.56 & 0.60 \\
\hline A15 & 0.78 & 0.89 & 0.67 & 0.78 & 0.90 \\
\hline A16 & 1.00 & 0.78 & 0.67 & 0.78 & 0.80 \\
\hline A17 & 0.78 & 0.67 & 0.89 & 0.89 & 0.70 \\
\hline A18 & 0.89 & 1.00 & 0.78 & 0.78 & 0.80 \\
\hline A19 & 0.89 & 0.67 & 0.78 & 0.67 & 0.70 \\
\hline A20 & 1.00 & 1.00 & 0.78 & 0.56 & 0.70 \\
\hline A21 & 0.78 & 0.89 & 0.78 & 0.78 & 1.00 \\
\hline A22 & 0.78 & 0.89 & 0.78 & 0.67 & 0.70 \\
\hline A23 & 0.89 & 0.78 & 0.89 & 0.67 & 0.80 \\
\hline A24 & 0.78 & 0.78 & 0.67 & 0.89 & 0.90 \\
\hline A25 & 0.89 & 1.00 & 0.89 & 0.78 & 1.00 \\
\hline A26 & 0.78 & 0.89 & 0.67 & 0.78 & 0.70 \\
\hline A27 & 0.89 & 1.00 & 0.78 & 1.00 & 0.70 \\
\hline A28 & 1.00 & 0.78 & 0.78 & 0.89 & 0.60 \\
\hline A29 & 0.89 & 0.67 & 0.78 & 0.67 & 1.00 \\
\hline A30 & 0.78 & 0.67 & 0.78 & 0.89 & 0.90 \\
\hline A31 & 0.78 & 0.78 & 0.89 & 0.67 & 0.70 \\
\hline A32 & 1.00 & 0.78 & 0.78 & 0.89 & 0.60 \\
\hline A33 & 0.78 & 0.67 & 0.89 & 1.00 & 0.90 \\
\hline A34 & 0.89 & 0.89 & 1.00 & 0.67 & 0.70 \\
\hline A35 & 0.89 & 1.00 & 0.78 & 0.78 & 0.90 \\
\hline A36 & 0.67 & 0.78 & 0.78 & 0.89 & 0.80 \\
\hline A37 & 1.00 & 0.78 & 0.78 & 0.78 & 0.80 \\
\hline A38 & 0.89 & 0.78 & 0.89 & 0.67 & 0.70 \\
\hline A39 & 0.89 & 0.89 & 0.78 & 0.89 & 0.60 \\
\hline A40 & 0.78 & 0.78 & 0.67 & 0.78 & 0.70 \\
\hline A41 & 0.89 & 0.78 & 0.78 & 0.67 & 0.80 \\
\hline & 1.00 & 0.78 & 0.89 & 0.67 & 1.00 \\
\hline A44 & 0.89 & 1.00 & 0.78 & 1.00 & 0.70 \\
\hline & & & & & \\
\hline
\end{tabular}




\begin{tabular}{|l|l|l|l|l|l|} 
A45 & 0.89 & 0.78 & 0.89 & 0.78 & 0.70 \\
\hline A46 & 0.78 & 0.67 & 0.78 & 0.89 & 0.70 \\
\hline A47 & 1.00 & 0.89 & 0.78 & 0.78 & 0.80 \\
\hline A48 & 0.78 & 0.89 & 0.78 & 0.89 & 0.60 \\
\hline A49 & 1.00 & 0.89 & 0.78 & 0.89 & 0.90 \\
\hline A50 & 0.89 & 0.78 & 0.89 & 0.78 & 0.70 \\
\hline A51 & 0.89 & 0.89 & 0.78 & 0.89 & 0.90 \\
\hline A52 & 1.00 & 0.89 & 1.00 & 0.78 & 0.70 \\
\hline A53 & 0.78 & 0.67 & 0.67 & 0.78 & 0.80 \\
\hline A54 & 0.67 & 0.78 & 0.78 & 0.89 & 0.70 \\
\hline A55 & 0.78 & 0.78 & 0.89 & 0.78 & 0.80 \\
\hline A56 & 0.89 & 0.67 & 0.67 & 0.78 & 0.80 \\
\hline A57 & 0.78 & 0.78 & 0.89 & 0.78 & 0.80 \\
\hline A58 & 0.89 & 0.78 & 0.78 & 0.89 & 0.80 \\
\hline A59 & 0.89 & 0.78 & 1.00 & 0.89 & 0.70 \\
\hline A60 & 0.67 & 0.78 & 0.67 & 0.89 & 0.70 \\
\hline A61 & 0.89 & 0.78 & 0.89 & 0.78 & 0.90 \\
\hline A62 & 0.78 & 0.67 & 0.89 & 0.78 & 0.80 \\
\hline A63 & 1.00 & 0.89 & 0.78 & 0.89 & 0.70 \\
\hline A64 & 1.00 & 0.78 & 0.78 & 0.89 & 0.60 \\
\hline A65 & 0.78 & 0.89 & 0.78 & 0.89 & 0.90 \\
\hline A66 & 1.00 & 0.89 & 0.78 & 0.78 & 0.80 \\
\hline A67 & 0.78 & 0.78 & 0.89 & 0.67 & 0.80 \\
\hline A68 & 0.89 & 0.78 & 0.78 & 0.89 & 0.60 \\
\hline A69 & 1.00 & 0.78 & 0.78 & 0.89 & 0.70 \\
\hline A70 & 0.78 & 0.78 & 0.89 & 0.89 & 0.70 \\
\hline A71 & 0.89 & 0.78 & 0.89 & 1.00 & 0.70 \\
\hline A72 & 0.78 & 0.89 & 1.00 & 0.78 & 1.00 \\
\hline A73 & 1.00 & 0.67 & 0.78 & 0.78 & 0.80 \\
\hline A74 & 0.67 & 0.89 & 0.89 & 0.78 & 1.00 \\
\hline A75 & 1.00 & 0.78 & 0.78 & 0.89 & 0.80 \\
\hline
\end{tabular}

\section{Membuat Keputusan}

Melakukan proses penilaian dengan cara mengalikan matriks ternormalisasi dengan nilai bobot yang diambil dari prioritas pada Tabel 2 . Data hasil keputusan ditunjukkan pada pada Tabel 7.

Tabel 7. Hasil Keputusan

\begin{tabular}{|c|c|c|c|c|c|c|c|}
\hline \multirow{2}{*}{ A } & \multicolumn{5}{|c|}{ Kriteria } & Jml & Ket \\
\cline { 2 - 8 } & C1 & C2 & C3 & C4 & C5 & & \\
\hline A1 & 0.31 & 0.09 & 0.11 & 0.05 & 0.07 & 0.62 & TL \\
\hline A2 & 0.18 & 0.09 & 0.11 & 0.08 & 0.05 & 0.51 & TL \\
\hline
\end{tabular}

\begin{tabular}{|c|c|c|c|c|c|c|c|}
\hline A3 & 0.36 & 0.17 & 0.07 & 0.04 & 0.04 & 0.68 & TL \\
\hline A4 & 0.27 & 0.14 & 0.13 & 0.07 & 0.05 & 0.66 & $\mathrm{TL}$ \\
\hline A5 & 0.18 & 0.17 & 0.09 & 0.08 & 0.06 & 0.59 & TL \\
\hline A6 & 0.22 & 0.23 & 0.13 & 0.08 & 0.04 & 0.7 & TL \\
\hline A7 & 0.31 & 0.2 & 0.11 & 0.1 & 0.06 & 0.78 & TL \\
\hline A8 & 0.36 & 0.2 & 0.13 & 0.07 & 0.07 & 0.83 & $\mathrm{~L}$ \\
\hline A9 & 0.36 & 0.17 & 0.13 & 0.06 & 0.04 & 0.76 & TL \\
\hline A10 & 0.22 & 0.2 & 0.09 & 0.1 & 0.06 & 0.67 & TL \\
\hline A11 & 0.27 & 0.2 & 0.13 & 0.07 & 0.05 & 0.72 & TL \\
\hline A 12 & 0.31 & 0.17 & 0.15 & 0.08 & 0.05 & 0.76 & TL \\
\hline A13 & 0.31 & 0.17 & 0.13 & 0.07 & 0.05 & 0.73 & TL \\
\hline A14 & 0.36 & 0.2 & 0.13 & 0.06 & 0.04 & 0.79 & TL \\
\hline A15 & 0.31 & 0.23 & 0.11 & 0.08 & 0.06 & 0.8 & TL \\
\hline A16 & 0.4 & 0.2 & 0.11 & 0.08 & 0.05 & 0.85 & $\mathrm{~L}$ \\
\hline A17 & 0.31 & 0.17 & 0.15 & 0.1 & 0.05 & 0.77 & TL \\
\hline A18 & 0.36 & 0.26 & 0.13 & 0.08 & 0.05 & 0.88 & $\mathrm{~L}$ \\
\hline A19 & 0.36 & 0.17 & 0.13 & 0.07 & 0.05 & 0.78 & TL \\
\hline A 20 & 0.4 & 0.26 & 0.13 & 0.06 & 0.05 & 0.89 & $\mathrm{~L}$ \\
\hline $\mathrm{A} 21$ & 0.31 & 0.23 & 0.13 & 0.08 & 0.07 & 0.82 & $\mathrm{~L}$ \\
\hline A22 & 0.31 & 0.23 & 0.13 & 0.07 & 0.05 & 0.79 & $\mathrm{TL}$ \\
\hline A23 & 0.36 & 0.2 & 0.15 & 0.07 & 0.05 & 0.83 & $\mathrm{~L}$ \\
\hline A24 & 0.31 & 0.2 & 0.11 & 0.1 & 0.06 & 0.78 & $\mathrm{TL}$ \\
\hline A25 & 0.36 & 0.26 & 0.15 & 0.08 & 0.07 & 0.91 & $\mathrm{~L}$ \\
\hline A26 & 0.31 & 0.23 & 0.11 & 0.08 & 0.05 & 0.78 & $\mathrm{TL}$ \\
\hline A 27 & 0.36 & 0.26 & 0.13 & 0.11 & 0.05 & 0.9 & $\mathrm{~L}$ \\
\hline A28 & 0.4 & 0.2 & 0.13 & 0.1 & 0.04 & 0.87 & $\mathrm{~L}$ \\
\hline A29 & 0.36 & 0.17 & 0.13 & 0.07 & 0.07 & 0.8 & TL \\
\hline A 30 & 0.31 & 0.17 & 0.13 & 0.1 & 0.06 & 0.77 & $\mathrm{TL}$ \\
\hline A 31 & 0.31 & 0.2 & 0.15 & 0.07 & 0.05 & 0.78 & $\mathrm{TL}$ \\
\hline A 32 & 0.4 & 0.2 & 0.13 & 0.1 & 0.04 & 0.87 & $\mathrm{~L}$ \\
\hline A33 & 0.31 & 0.17 & 0.15 & 0.11 & 0.06 & 0.8 & $\mathrm{~L}$ \\
\hline A34 & 0.36 & 0.23 & 0.17 & 0.07 & 0.05 & 0.87 & $\mathrm{~L}$ \\
\hline A35 & 0.36 & 0.26 & 0.13 & 0.08 & 0.06 & 0.89 & $\mathrm{~L}$ \\
\hline A 36 & 0.27 & 0.2 & 0.13 & 0.1 & 0.05 & 0.75 & TL \\
\hline A37 & 0.4 & 0.2 & 0.13 & 0.08 & 0.05 & 0.87 & $\mathrm{~L}$ \\
\hline A38 & 0.36 & 0.2 & 0.15 & 0.07 & 0.05 & 0.82 & $\mathrm{~L}$ \\
\hline A39 & 0.36 & 0.23 & 0.13 & 0.1 & 0.04 & 0.85 & $\mathrm{~L}$ \\
\hline A40 & 0.31 & 0.2 & 0.11 & 0.08 & 0.05 & 0.75 & TL \\
\hline A41 & 0.36 & 0.2 & 0.13 & 0.07 & 0.05 & 0.81 & $\mathrm{~L}$ \\
\hline A42 & 0.4 & 0.2 & 0.15 & 0.07 & 0.07 & 0.89 & $\mathrm{~L}$ \\
\hline
\end{tabular}




\begin{tabular}{|c|c|c|c|c|c|c|c|}
\hline A43 & 0.36 & 0.26 & 0.13 & 0.11 & 0.05 & 0.9 & $\mathrm{~L}$ \\
\hline A44 & 0.4 & 0.2 & 0.13 & 0.1 & 0.05 & 0.87 & $\mathrm{~L}$ \\
\hline A45 & 0.36 & 0.2 & 0.15 & 0.08 & 0.05 & 0.84 & $\mathrm{~L}$ \\
\hline A46 & 0.31 & 0.17 & 0.13 & 0.1 & 0.05 & 0.76 & TL \\
\hline A47 & 0.4 & 0.23 & 0.13 & 0.08 & 0.05 & 0.9 & $\mathrm{~L}$ \\
\hline A48 & 0.31 & 0.23 & 0.13 & 0.1 & 0.04 & 0.81 & $\mathrm{~L}$ \\
\hline A49 & 0.4 & 0.23 & 0.13 & 0.1 & 0.06 & 0.92 & $\mathrm{~L}$ \\
\hline A50 & 0.36 & 0.2 & 0.15 & 0.08 & 0.05 & 0.84 & $\mathrm{~L}$ \\
\hline A51 & 0.36 & 0.23 & 0.13 & 0.1 & 0.06 & 0.87 & $\mathrm{~L}$ \\
\hline A52 & 0.4 & 0.23 & 0.17 & 0.08 & 0.05 & 0.93 & $\mathrm{~L}$ \\
\hline A53 & 0.31 & 0.17 & 0.11 & 0.08 & 0.05 & 0.73 & TL \\
\hline A54 & 0.27 & 0.2 & 0.13 & 0.1 & 0.05 & 0.74 & $\mathrm{TL}$ \\
\hline A55 & 0.31 & 0.2 & 0.15 & 0.08 & 0.05 & 0.8 & $\mathrm{TL}$ \\
\hline A56 & 0.36 & 0.17 & 0.11 & 0.08 & 0.05 & 0.78 & TL \\
\hline A57 & 0.31 & 0.2 & 0.15 & 0.08 & 0.05 & 0.8 & $\mathrm{TL}$ \\
\hline A58 & 0.36 & 0.2 & 0.13 & 0.1 & 0.05 & 0.84 & $\mathrm{~L}$ \\
\hline A59 & 0.36 & 0.2 & 0.17 & 0.1 & 0.05 & 0.87 & $\mathrm{~L}$ \\
\hline A60 & 0.27 & 0.2 & 0.11 & 0.1 & 0.05 & 0.72 & TL \\
\hline A61 & 0.36 & 0.2 & 0.15 & 0.08 & 0.06 & 0.85 & $\mathrm{~L}$ \\
\hline A62 & 0.31 & 0.17 & 0.15 & 0.08 & 0.05 & 0.77 & TL \\
\hline A63 & 0.4 & 0.23 & 0.13 & 0.1 & 0.05 & 0.9 & $\mathrm{~L}$ \\
\hline A64 & 0.4 & 0.2 & 0.13 & 0.1 & 0.04 & 0.87 & $\mathrm{~L}$ \\
\hline A65 & 0.31 & 0.23 & 0.13 & 0.1 & 0.06 & 0.83 & $\mathrm{~L}$ \\
\hline A66 & 0.4 & 0.23 & 0.13 & 0.08 & 0.05 & 0.9 & $\mathrm{~L}$ \\
\hline A67 & 0.31 & 0.2 & 0.15 & 0.07 & 0.05 & 0.79 & TL \\
\hline A68 & 0.36 & 0.2 & 0.13 & 0.1 & 0.04 & 0.82 & $\mathrm{~L}$ \\
\hline A69 & 0.4 & 0.2 & 0.13 & 0.1 & 0.05 & 0.87 & $\mathrm{~L}$ \\
\hline A70 & 0.31 & 0.2 & 0.15 & 0.1 & 0.05 & 0.8 & $\mathrm{~L}$ \\
\hline A71 & 0.36 & 0.2 & 0.15 & 0.11 & 0.05 & 0.86 & $\mathrm{~L}$ \\
\hline A72 & 0.31 & 0.23 & 0.17 & 0.08 & 0.07 & 0.86 & $\mathrm{~L}$ \\
\hline A73 & 0.4 & 0.17 & 0.13 & 0.08 & 0.05 & 0.84 & $\mathrm{~L}$ \\
\hline A74 & 0.27 & 0.23 & 0.15 & 0.08 & 0.07 & 0.79 & TL \\
\hline A75 & 0.4 & 0.2 & 0.13 & 0.1 & 0.05 & 0.88 & $\mathrm{~L}$ \\
\hline
\end{tabular}

memperoleh pinjaman. Keputusan diperoleh dari ketetapan dari persyaratan yang telah ditentukan oleh pihak koperasi, yaitu besar sama 80 persen $(\geq 80 \%)$ dari total kriteria yang telah ditetapkan.

Data yang digunakan adalah data pemberian kredit kepada nasabah 1 tahun terakhir sebanyak 75 nasabah. Dari data tersebut terdapat 40 nasabah yang lancar dan 35 nasabah tidak lancar, artinya akurasi metode saat ini 40:75=53\%. Berdasarkan metode yang diusulkan, yaitu metode AHP dan SAW 40 nasabah yang lancar, dihasilkan 37 nasabah yang lancar dan 3 nasabah tidak lancar. 35 nasabah yang tidak lancar, dihasilkan 31 nasabah tidak lancar dan 4 nasabah yang lancar. Artinya menurut metode AHP dan SAW tepat $37+31=68$ dan tidak tepat $3+4=7$. Akurasi AHP dan SAW adalah $68: 75=90.67 \%$.

\section{Implementasi}

Metode Analytical Hierarchy Process (AHP) dan Simple Additive Weighting (SAW) disimulasikan menggunakan aplikasi berbasis desktop. Hasil implementasi sistem yang telah dilakukan pada Koperasi Simpan Pinjam Cipta Harapan Jaya seperti pada Gambar 1, Ganbar 2, Gambar 3 dan Gambar 4.

1. Form Entri Data Calon Nasabah

Implementasi antarmuka data calon nasabah. Admin dapat mengelola data calon nasabah yang mengajukan pinjaman seperti pada Gambar 1.

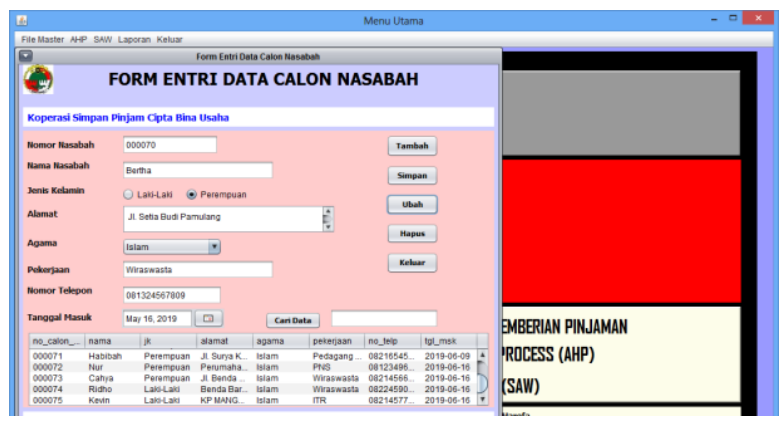

Angka 0.31 pada kolom collateral didapat dari hasil perkalian nilai collateral (0.78) pada Tabel 6 dengan nilai prioritas (0.40) pada Tabel 2. Angka-angka yang lain didapat dengan cara yang sama, yaitu dengan mengalikan nilai kriteria dengan nilai prioritas. Jumlah didapat dari hasil penjumlahan nilainilai kriteria yang didapatkan. Semakin tinggi nilai jumlah semakin berpeluang untuk

\section{Gambar 1. Data Calon Nasabah}

\section{Form Penghitungan Nilai Prioritas Kriteria} Implementasi antarmuka data matriks perbandingan kriteria. Admin dapat mengelola data matriks perbandingan kriteria seperti pada Gambar 2. 


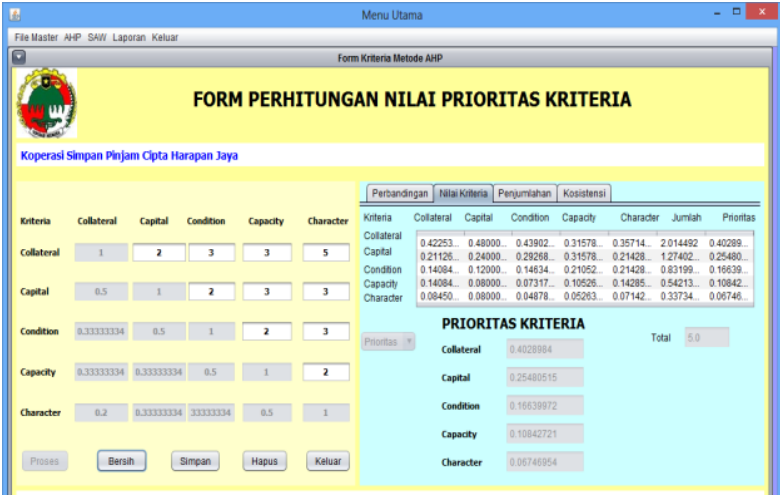

Gambar 2. Penghitungan Nilai Prioritas Kriteria

\section{Form Pengambilan Keputusan}

Implementasi antarmuka nilai setiap nasabah. Admin dapat mengelola kriteriakriteria pada setiap nasabah seperti pada Gambar 3.

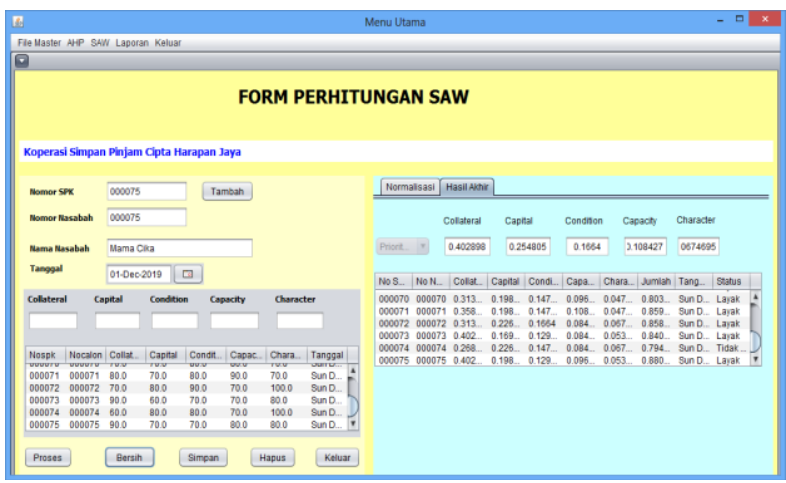

Gambar 3. Pengambilan Keputusan

\section{Form Cetak Laporan Keputusan}

Tampilan laporan nasabah merupakan tampilan untuk mencetak laporan hasil pemeringkatan dari penghitungan AHP dan SAW dari sistem tersebut seperti pada Gambar 4.

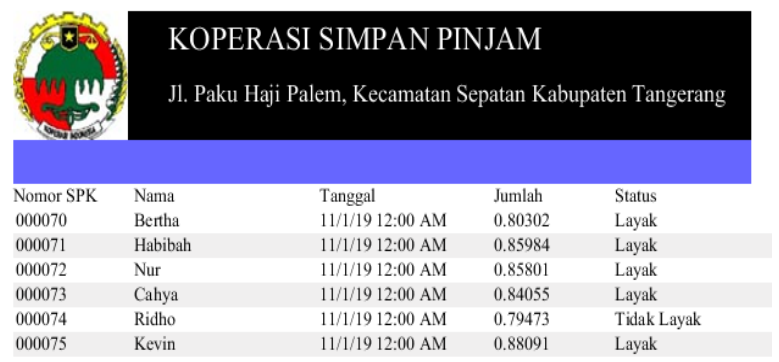

Gambar 4. Tampilan Cetak Laporan Keputusan

\section{Kesimpulan}

Berdasarkan hasil penghitungan dan implementasi sistem pendukung keputusan yang diusulkan, yaitu metode Analytical Hierarchy Process (AHP) dan Simple Additive Weighting (SAW) didapat akurasi 90,67\%. Artinya akurasi ini mendekati nilai baik dan dapat dijadikan salah satu pedoman untuk menentukan calon nasabah yang layak mendapatkan pinjaman.

\section{Referensi}

Anita, M., \& Purnomo, A. S. (2019). Sistem Pendukung Keputusan Pengajuan Kredit Menggunakan Simple Additive Weighting (SAW) (Studi Kasus Bank BPD DIY). SINTAK, 106-114.

Wibowo, A., \& Keanu, K. (2017). Sistem Pendukung Keputusan Penilaian Kelayakan Kredit Menggunakan Metode Simple Additive Weighting (SAW). Journal of Applied Informatics and Computing (JAIC), 22-25.

Armana, I. M. R., Trisna, N. H., \& Erni, S. (2015). Analisis Faktor-Faktor Penyebab Terjadinya Kredit Macet pada Lembaga Perkreditan Desa (LPD) di Kabupaten Buleleng. e-Journal S1 Ak Universitas Pendidikan Ganesha, 1-10.

Bayu, M. I. P., \& Anwar, S. (2018). Pemodelan Sistem Pendukung Keputusan Pemberian Kredit dengan Metode AHP Berbasis Web Mobile. Prosiding SENDI_U (pp. 295-301). Semarang: Prosiding SENDI_U.

Chosyali, A., \& Sartono, T. (2019). Optimalisasi Peningkatan Kualitas Kredit dalam Rangka Mengatasi Kredit Bermasalah. Law Reform, 98-112.

Dedeh, S. S., \& Nana, S. (2017). Analisis Kesehatan Koperasi Simpan Pinjam Berdasarkan Aspek Permodalan, Manajemen, Likuiditas, serta Kemandirian dan Pertumbuhan. Jurnal Ekonomi Manajemen, 1-10.

Ernawati, Nur, A. H., \& Elvi, F. (2017). Rancang Bangun Sistem Pendukung Keputusan Kenaikan Jabatan Pegawai dengan Metode Profile Matching (Studi Kasus: Kementerian Agama Kantor Wilayah DKI Jakarta). Jurnal Sistem Informasi, 127-134.

Faiza, I. N., Diana, N., \& Cholid, M. M. (2018). Analisis Faktor-Faktor Penyebab Terjadinya Kredit Bermasalah (Studi pada Perusahaan Perbankan yang Terdaftar di. E-JRA, 113-126.

Kitnas, D. P., \& Feddy, S. P. (2015). Implementasi Sistem Pendukung Keputusan Peminatan Peserta Didik SMA menggunakan Metode AHP (Analytic Hierarchy Process) dan SAW (Simple Additive Weighting). Jurnal Teknik Elektro, 57-61. 
Nursyahriana, A., Michael, H., \& Irsan, T. (2017). Analisis Faktor Penyebab Terjadinya Kredit Macet. Forum Ekonomi, 1-14.

Sabri. (2016). Analisis Persepsi Nasabah Terhadap Faktor-Faktor yang Mempengaruhi Kredit Macet pada PT. Bank Perkreditan Rakyat (BPR) Padang Tarab Kecamatan Baso Kabupaten Agam. Jurnal Ekonomi STIE Haji Agus Salim, 218-230.

Siti, F. R., Nurul, H., \& Suprapto. (2018). Sistem Pendukung Keputusan Rekomendasi Pemberian Usaha Kredit Mikro (UKM) dengan Metode AHP-SAW (Study Kasus: PD. BPR Bojonegoro). Jurnal Pengembangan Teknologi Informasi dan Ilmu Komputer, 2620-2627.

Suarjaya, I. N. (2015). Analisis Penyelesaian Kredit Macet pada Koperasi Pasar Srinadi Klungkung. Jurnal Jurusan Pendidikan Ekonomi Undiksha, 1-11.

Suci, R. S., \& Nurhayati. (2018). Sistem Pendukung Keputusan Pemberian Kredit PNS dengan Metode AHP dan TOPSIS. Jurnal Teknik Informatika Kaputama (JTIK), 35-45.

Suryani, K. A., Ustriyana, I. N., \& Wulandira, S. (2016). Analisis Kredit Macet pada KPN Satya Bakti. E-Jurnal Agribisnis dan Agrowisata, 1-10. 